\title{
GENDER MAINSTREAMING IN THE CONTEXT OF ACEH DEVELOPMENT
}

\author{
GUNAWAN ADNAN \\ UIN Ar-Raniry-Banda Aceh \\ gunawanadnan.arraniry@gmail.com
}

\begin{abstract}
Gender mainstreaming is a globally accepted strategy for promoting gender equality. Mainstreaming is not an end in itself but a strategy, an approach, a means to achieve the goal of gender equality. Mainstreaming involves ensuring that gender perspectives and attention to the goal of gender equality are central to all activities - policy development, research, advocacy/dialogue, legislation, resource allocation, and planning, implementation and monitoring of programs and projects. Gender mainstreaming is, therefore, becoming a collective awareness and concern in most countries since it is viewed as one of the most appropriate, comprehensive and representative approaches to solve both the problem of gender inequality and the problem of violence against women and children including in Indonesia in general and Aceh in particular. This study is aimed at exploring how gender mainstreaming initiatives, attempts to integrate a gender equality approach to post-tsunami and post-conflict reconstruction and development efforts in Aceh, take part in the social and political reconstruction by both reproducing and subverting gendered images of temporality and spatiality as well as promoting a holistic gender equality in all aspects of life. The method used in doing this research is a library method in which all related data and library resources are collected, examined and finally analyzed. The result of this study suggests, among others, that gender mainstreaming should be based on a holistic approach, not only in spirit and conceptual basis but also in practical and social reality basis, such as empowering women in having equal access toward education, access to economic resources, access to the right of possessing property, etc. Moreover, one of another important result of this study is that the violence against women and children that still commonly occur almost everywhere in the world should be viewed as collective enemy and challenge which needs to be faced and eliminated collectively as well.
\end{abstract}

Keywords: Gender Mainstreaming and Aceh Development.

\begin{abstract}
ABSTRAK
Pengarusutamaan gender adalah strategi yang diterima secara global untuk mempromosikan kesetaraan jender. Pengarusutamaan bukanlah tujuan tersendiri melainkan strategi, pendekatan, sarana untuk mencapai tujuan kesetaraan jender. Pengarusutamaan melibatkan memastikan babwa perspektif gender dan perhatian terhadap tujuan kesetaraan gender sangat penting dalam semua kegiatan pengembangan kebijakan, penelitian, advokasi / dialog, legislasi, alokasi sumber daya, dan perencanaan, pelaksanaan dan pemantauan program dan proyek. Pengarusutamaan gender, oleh karena itu, menjadi kesadaran kolektif dan perhatian di sebagian besar negara karena dipandang sebagai salah satu pendekatan yang paling tepat, komprehensif dan representatif untuk memecabkan masalah ketidaksetaraan gender dan masalah kekerasan terhadap perempuan dan anak-anak termasuk di
\end{abstract}


Indonesia. secara umum dan Aceh pada khususnya. Penelitian ini bertujuan untuk mengeksplorasi bagaimana inisiatif pengarusutamaan gender, upaya untuk mengintegrasikan pendekatan kesetaraan jender terbadap upaya rekonstruksi dan pembangunan pasca-tsunami dan pascakonflik di Aceh, ambil bagian dalam rekonstruksi sosial dan politik dengan mereproduksi dan menumbangkan citra temporalitas gender. dan spasial serta mempromosikan kesetaraan jender holistik dalam semua aspek kehidupan. Metode yang digunakan dalam melakukan penelitian ini adalah metode perpustakaan dimana semua sumber data dan perpustakaan terkait dikumpulkan, diperiksa dan akbirnya dianalisis. Hasil penelitian ini mengemukakan, antara lain, pengarusutamaan gender harus didasarkan pada pendekatan holistik, tidak hanya berdasarkan semangat dan konseptual, tetapi juga dalam basis realitas praktis dan sosial, seperti memberdayakan perempuan dalam memiliki akses yang setara terbadap pendidikan, akses terhadap sumber daya ekonomi, akses terhadap hak memiliki properti, dan sebagainya. Selain itu, salah satu hasil penting lainnya dari penelitian ini adalah bahwa kekerasan terbadap perempuan dan anakanak yang masih sering terjadi hampir di mana-mana di dunia harus dipandang sebagai musub kolektif dan tantangan yang dibutubkan. untuk dibadapi dan dibilangkan secara kolektifjuga.

Kata kunci: Pengarusutamaan Gender dan Pembangunan Aceh.

\section{A. INTRODUCTION}

Gender equality and justice, which are well-known in Indonesian abbreviation as KKG (Kesetaraan dan Keadilan Gender) have been one of the most phenomenal and always actual issues. This issue has attracted and enjoyed international commitment and serious attention including Indonesia - even though at the implementation level it seems to be still so weak and unsatisfactory- so that the issue become as a compulsory for all nations and countries to achieve that commitment.

As a country, that is so concerned and committed to the commitment of gender equality and justice, Indonesia has already formulated this hot issue in its national policy as it is officially declared in national regulation which is well-known as GBHN 1999, UU No. 25, 2000 about national development program or PROPENAS 2000-2004, and it is strengthened by the president instruction, no. 9, 2000, on Gender Mainstreaming in national development as one of strategies in achieving gender equality and justice (United Nations).

The fact that gender mainstreaming is taken into national or even international serious consideration is not without any logical reason or just to imitate an international trend. It is a social necessity and responsibility of a nation, country, etc. to solve its significant gender gap which potentially leads to social instability and injustice. The gender gap which is a common phenomenon in almost all countries in all parts of the world -not only in developing but also in developed countries- has been contributing much social turbulence not only for the women, but also for men. It is because that this gender gap may directly or indirectly influence the speeding up process of development 
including the process of rehabilitation and reconstruction of Aceh province after the Tsunami of December 26, 2004, that did not only destruct most infrastructure in Aceh, but also take hundreds thousand of lives. This concise paper is aimed at briefly elaborating gender mainstreaming and its challenge including the violence against women and children in designing a comprehensive plan in building back Aceh better in the future.

\section{B. LITERATURE REVIEW}

1. Collective Development

The vertical conflict that had been faced by the Acehnese for more than thirty years created many negative impacts on the Acehnese community and contributed a huge problems and stagnations for the continuity of Aceh development. Therefore, it is not wondering if the development scale in Aceh much less improved than that of most other provinces in Indonesia. Aceh is then not only less or stagnant in term of physical development sector, but in the non-physical sector as well, particularly in human resources development, such as education, women empowerment, etc. The Acehnese women are the most vulnerable and suffered group of the Acehnese community. They are not only forced to be mothers who have limited capacity and income, but -due to the conflict- they have also to be single parents to their children who left by their late husbands, who died in the conflict or weapon clash with the Indonesian military or who had to live in the jungle or forest for guerilla (Schulze, E. Kirsten E., 2014).

The conditions of the Acehnese women, who have been trapped in a disadvantageous and suffered from the quite long conflict, had been then worsening by the horrible and killing Tsunami. These, of course, added and completed the black page of Acehnese people tragedy, especially Acehnese women, who suffered most and belong to the vulnerable group due to their over burden responsibility as mothers and -at the same time- as fathers (single parents) to their children. Despite the victims of the Tsunami were not only women, but also men, the fact depicts that the position of the Acehnese women have become worse and worse after the Tsunami (Schulze, E. Kirsten E., 2014).

The Acehnese women who do not only active in the domestic sphere, but also public ones have to face a harder and disadvantageous situation now, particularly in 
economic sectors. For instance, before Tsunami there were many women who worked outside their houses i.e in the markets, rice fields, etc. to support their husbands in fulfilling their primary or daily basic need. Now, they have to lose their jobs and access to economics resources (income) because most of their working places were totally ruined by the Tsunami (Schulze, E. Kirsten E., 2014). From these phenomena one can imagine the fate of these powerless and unlucky women (wives) if one or some of them is/are left by her/their husbands who died in the horrible Tsunami; of course, the picture of their fates is very sorrow.

It is said that the Tsunami disaster that had badly destructed Nanggroe Aceh Darussalam province, particularly its coastal area, is like the so-called the blessing in disguise. This expression might be emerging because people may clearly see that due to Tsunami disaster Aceh has attracted and enjoyed International concern and attention. As a logical consequence from that view, Aceh obtains many donations from all over the worlds; and because of the Tsunami and national as well as international donations a board for Rehabilitation and Reconstruction of Aceh and Nias, which is well-known as BRR, has been established. The main task of this board is to ensure, coordinate and speed up the process of Rehabilitation and Reconstruction in Aceh and Nias after Tsunami and earthquake. BRR, unfortunately, seems to be mislead and mismanagement so that it is no wonder if it, almost every day, receives many sharp critics and blame or even demonstrations both from its stakeholders and beneficiaries (BRR Aceh, 2005 - 2008).

Regarding the issue of Aceh development including the process of Aceh reconstruction, it is important to post a radical, but very important question i.e "to whom the reconstruction and development in Aceh to be devoted?". The answer is very clear that all these activities are aimed at achieving an equal social prosperity and justice of all Acehnese community. Like any other community, the Acehnese community consists not only of men but also women, children, and the oldies. Women constitute more than half of the Acehnese total demography. Based on this fact, one may understand the importance of women role and participation in the process of development and reconstruction in Aceh; and he/she must be aware of the stagnation and backwardness if women are neglected or put behind in the process of Aceh development. Since the concept of a good and real development must be based on the motto "from all people, for all people and by all people" the 
development must be done and achieved collectively meaning by all people of the society, including women. Without being collectively participated and supported by all elements of the society, the development must be facing many obstacles and most probably unsuccessful.

It is a common phenomenon that in the real social life one tends to be ignorant towards women's role. Women roles seem to be neglected and underestimated in daily life, why? To answer the word "why" is not an easy matter. There are many driven factors that lead women to the so-called marginalized position. Among other things, -believe it or not-, it is the result of the domination of patriarchal system adopted in social structure and daily life, in which women tend to be viewed as less powerful and productive than men. This patriarchal domination has inevitably put women as the looser of an athletic race; and the fact that women lose the race or the game is very logical and it is not solely because they are women, who are physically different from men, but it is really due to the injustice system applied in the society (Hakim, 1999). If we refer to an athletic race, we may say that men have already run in the middle of the race track, whereas women are still on the start line. How can, then women win the race? It is, of course, impossible and illogical for women to win the game.

One has to confess that men have very good access to the education and economic resources, while women have and enjoy much less access that the men do. So, if this condition keeps going on, women will have no chance to win the race, which means that women will always be marginalized or the looser since men has cheated them in doing start. In other word, men's position is socially more advantageous than that of women. From this analog one could understand of why women are facing many obstacles and not so involved in the process of development. Therefore, there is no other choice to change this social injustice and unhealthy than to empower women, especially through education, trainings, workshops, advocacy, etc. Why is empowerment important? Everybody may agree that without empowerment process, women will always be defeated by their social system which tends to be so patriarchal. Empowerment will enable women to shorten and fill the gap between them and men (UNDP, 2004). Apart from that, through empowerment women will be able to improve their capacity to take an active part in the process of development. This situation or analog holds also true to 
the context of Acehnese women, who -according to my opinion- must be more prioritized to be empowered since they have been facing more difficult and disadvantageous history and situation than that of any other women in Indonesia. There are many essential things that have to be done in term of empowering women, among others:

a. The access towards education

Despite Indonesian Law (regulation) guarantees that all citizens have the same rights and access to education, we have to confess that there are still many Indonesian, especially Indonesian women (girls), who have no access to education. As an instance to that end, one may easily find that there are many illiterate people in Indonesia, both men and women. Illiteracy is a serious and real enemy of development. Therefore, providing the same and equal access to education for all citizens both men (boys) and women (girls) is one of the most crucial and urgent responsibilities of the government and in the Aceh context is the Aceh government and it's related and respective institutions.

It is undeniable that women are socially disadvantageous, among other things, by being stereotyped as being created to hold domestic roles, weak in term of physical things, etc. It is also said that it is not important what kind of degree a woman may get, her position is always linked to three areas namely sumur (well), kasur (mattress/bedroom) and dapur (kitchen). Ironically, such a stereotype seems to be accepted or even supported by women themselves as if it is a common sense truth. Such a stereotype can only be changed through education, women empowerment as well as men and women enlightenment. Education, for instance, is one of the most principal and fundamental aspect that should be first and foremost carried out in order to alter all silly stereotypes and bias mindset of our society as well as to upgrade the level of the capacity and character buildings of our society, particularly the women, who belong to the weakest group of our society.

b. The access to economic resources (job)

After being educationally empowered and they become a well-educated society, the next priority to be achieved is that they have to be given access to all economic resources, job opportunities and position as well as encouragement to actively participate in all steps of development in accordance with their respective 
competencies and skills. Without opening this opportunity or giving access to life resources, the society will be ill or unhealthy which is potentially contributing, in its turn, many social turbulence and instabilities, such as criminality, social jealousy, and other social illnesses.

c. The access to decision-making board.

Women will always be the object of development if they will not be given the opportunity to have access to each decision-making process of the development policy. A social tradition which tends to ignore women's roles in almost all decision-making process must be now and without any excuses altered, especially regarding the rights to fulfill their basic needs, like having access to life resources (income), education, right to express ideas and other women-specific needs. If the above-mentioned needs and factors are neglected or ignored, it is sure that development and its result will not make them (the women) happy or satisfy, because men seem to be failed in understanding women's needs and characters. By involving women in the whole step of development -from the planning, budgeting, etc., to implementation and evaluation, etc.- the development will likely be able to ensure the fulfillment of men and women rights equally and simultaneously as well (Hakim, 1999).

d. The Access to the right of possessing property

It is quite fair and logical thing if skillful and/or well-educated women obtain or earn a proportional income and salary for their roles, skills, and competencies. Based on this consideration, it is a logical consequence if the women will be given the right to possess property or goods or whatever there is deriving from their own legal income or salary. We have to confess that this kind of right is still far from ideal not only in Aceh but also in Indonesia. It is like an untouchable area of our legal system. Like men, women are also human beings, who need right to possess some amounts of property or wealth based on their respective roles, responsibilities, and capacities. This right plays an important role in motivating women to work, contribute most and to do their best to support the prosperity of the country through their full participation in taking an active part in all process of the development, both at Aceh provincial level in particular and national level in general. By establishing the right of possessing wealth, it means that the country respects their rights and existence not only as the whole part of 
its citizen or nation but also as human being (United Nations). Psychologically, by doing so Aceh women will positively have the so-called self-confidence and social and psychological security which inspire them to be more productive, creative and independent in supporting the process of Aceh development in particular and the development of Indonesia in general. This is of important efforts to be formulated and achieved because it is very often in our society that a wife has to drop out their children's studies just because of the death of her husband and she becomes so dependent because she can do nothing outside her domestic role.

2. It needs a holistic approach and participation

In the context of Aceh development, it needs a holistic approach and participation which include and involve all elements of the Acehnese people including women. Based on this concept, the role of women cannot be represented by only, for instance, a Directorate for women affairs and children protection or the department for women rights, etc., because it will minimize women role and existence. The most important thing, according to my opinion, is how to improve the awareness of gender equality and gender mainstreaming in all sectors of development in Aceh (BRR quarterly report, 2008). Moreover, it is always critical to create link and match of all programs of the development, particularly between input and output as well as between planning, processing, organizing and evaluating, etc.

3. Women and Children Are Still The Victims Of Violence.

Women and children are still an element of the susceptible group among Indonesian society whose rights and positions tend to be violated. The violation that has generally been happening to women and children is still part of dangerous and serious social illness and a humanitarian problem which may occur everywhere including in Aceh. This kind of violation should be taken into our collective serious attention, not only the government but also all elements of our nation. This phenomenon reminds us on the so-called jabiliyyah time (the time of ignorance) in which the jungle law or barbarian life system was applied. This time is also called as the time of Herodes which gave unlimited and supreme rights to the ruler (Muhsin, 1992). This situation is quite ironical and contradictive in our society that is wellknown as an east cultural society who respect and practice a high standard of human values and tradition. The matter or question that is worth to be raised here is that is the morality and good values in our society declining or reducing now or what is 
happening to or in our society? The violation that is commonly experienced both by women and children are actually not a new phenomenon. The historical facts and books reveal horrible violation and anti-human rights practices to women both to adult women (the sacrifice in front of the altar) and to infant women (the killing of women babies), etc (Ahmed, 2000).

The story and note on women and children violations are very limited and not easily found in existing literatures and resources. Therefore, the victimization of women and children through violation is rarely exposed and revealed. No sufficient information and note are found regarding the case of women and children victimization through violation brought to the criminal court. The problem would probably be caused and influenced by the perception of society, either in general or particular -among women group- that the violations experienced by women and children are much better to hide rather than to expose or to bring to the criminal court, etc (Ahmed, 1997). This, of course, has a close relationship and connection to the existing and practicing values in the society regarding the position of women. Women mostly think that it is not a good and wise way to make a report or to expose the victimization or violation of their rights and to bring the case to the criminal court. Such a practice, according to the women is a great disgrace to them. Therefore, they prefer to keep silent and to hide the case rather than to bring it to the criminal court which they think will expose their disgrace and brush up their selfrespect or dignity.

As a result of this perception which may also be stated as misperception, the mass media sometimes practice a contra-productive thing which is well-known as "selective inattention" i.e selecting certain news to be presented for public or society consumption. This kind of news publication, at least, promotes victimization to women and children which commonly focused on the following issues, among others: a) Sexual violence ; b) Child sexual abuse; c) The violence that causes severe injuries; d) The violence resulting in death; e) The case of incest, etc (Gosita, 1983).

Often there is also a perception that a female victim will think that she has a share in the crime, although it not. For example, rape, a female rape victim tends to keep her grief both psychic and physic because she thinks that her attendance to the law enforcement agency will only bring about double victimization to her. Moreover, various acts of violence happen very often and causes casualties among women such 
as, a) sexual assault; b) murder case of mother or grandmother both because of the economic motive and because of the irresistible anger; c) Pornography and pornoaction; d) Acts of violence by employers to domestic workers that commonly happens which is based on a sense of annoyance and even hatred, and some other acts of violence (Pecker, 1985). Similarly, victims of violence against children in sexual cases, in which the position of children are often regarded as a derivation of their parents, who are often make them helpless. For instance, incest acts or behavior that resulted in the child was forced to give birth to a baby who is the result of an incestuous relationship with their own parents. Besides, there are several cases related to child exploitation, persecution, and killing of children by their parents.

Broadly speaking, children who experience violence may occur because: (a) Working Children, in which many children are full-time children, child prostitution (child prostitution), child bondage, child pornography due to increased sex tourism; (b) Street children, where there are approximately 100 to 150 million street children around the world today (Ancel, 2012). The concern is that in addition to their struggle for material survival, it is also subject to abuse and exploitation, such as street thieves, street prostitution, drug trade, and other organized crime activities; (c) Children in Armed Conflict, where in conflict situation, many children who are victims, such as killed, disabled, displaced and even missing. Not to mention the victims of rape and suffering from psychiatric stress (stress and trauma).

The difficult problem faced is how to do their coaching and reorientation from situation/culture of conflict to culture of peace; (d) Urban war zones, where an atmosphere of violence and non-lingering in everyday life environments both in the city and in the "war zone" region puts children at grave risk, especially if there is poverty, the use of drugs and weapons and crime as a reality of everyday life. What is interesting to discuss next is whether the violence against women and children is the impact of the chaos of the norm which is called "anomie" that has now been experienced by various communities in Indonesia. This requires accurate research to answer it academically.

\section{Violence of Women is a Cultural and Structural Factors}

Violence against women still often occurs in a quite varied form. This violence against women no longer sees victims from a single dimension. However, many dimension, such as age, gender, social status, and so on, still places women as victims' 
objects. Violence against women can be categorized into several things such as smuggling, domestic violence, detention, rape, robbery, torture, murder, and trafficking or trafficking of women and children. Sri Wahyuningsih (2015) said this case of baby smuggling has shifted into a baby commerce system that is no longer humane (Wahyuningsih, 2015). This smuggling is done by adoption mode until the sale of victim's organs. Illegal trafficking in infants will be especially vulnerable through border areas, such as West Kalimantan and Aceh (Malacca Strait). This area is the most strategic area for the practice of smuggling of babies to Malaysia's neighbor country and being a bride booking for Taiwanese veteran men. "other trafficking patterns are prostitution, begging, female workforce which is well-known as TKW, domestic helpers employed as jermal (remote or offshore fishing camp) and plantations, as well as other sexual exploitation, such as pedophilia, including new growth kids which is famous as the ABG girls in waiting for long departures abroad as disguised TKW, , "she said (Wahyuningsih, 2015).

In addition, rape also places women as victims and these events are often carried out by close people or others. In fact, the perpetrators of rape could be people who have blood relationships like father, brother, grandfather, or even his own uncle. Worse yet, the act of rape is partly done not enough just once, often even until the victim is pregnant and gave birth to the child of the result of his dark or illegal relationship (Ancel, 2012). Even so, robbery often occurs with the victims of poor and wealthy women. The suffering of women as autonomous individuals and having strong sovereignty to be self-sufficient and enjoying the rights to enjoy life is also often the victim of sexual abuse. "Moreover, the case between husbands and wives in the household, if the problem is blown and known by the public, then women will be positioned as the most guilty because women will be considered to have failed and unable to satisfy the sex of the husband.

According to Aminah Wadud, the violence against women, generally, occurs due to two main factors namely culture and structure factors. Both influence each other and strengthen each other, thus eradicating violence against women requires a shared commitment to seriously, systematically and continuously in the fight against it (Wadud, 1992). According to her, this cultural factor stems from the values and norms that place men as decision-makers who have power or power, and are the parties that evaluate and monitor everything women have and do. This 
understanding is called patriarchal ideology. Patriarchal ideology will give birth to gender. "Meanwhile, the structural factor that could be the cause of violence against women and children is derived from institutions or institutions built to organize a common life called the state," she said.

Furthermore, violence cases against women and children in Indonesia are now becoming more and more widespread. Yet all components of government and civil society have struggled to overcome them. Why has the struggle so far been less effective? Is this a good time to "raise the status" of this issue to be parallel to terrorism and drugs? "Violence against women" in Law Number 23 of 2004 is defined as any act against a person, especially a woman, resulting in misery or suffering physically, sexually, psychologically, and / or abandoning the household including threats to do deeds, coercion, or unlawful deprivation of liberty within the scope of the household (UNDP, 2004).

Similarly, the notion of "violence against children" in Law No. 35 of 2014 is any act against children resulting in physical, psychological, sexual and/or neglect of misery or suffering, including threats of committing, coercing or unlawful deprivation of liberty. Although the consequences of the punishment are quite severe, and the government and civil society have worked hard to overcome it by spending funds and other resources that increasingly years of increasing, but cases of violence against women and children in this country actually getting worse and worrisome. It seems that the perpetrators of the violence are not clueless.

In 2015 alone, according to the National Commission for Women, there were at least 321,752 cases of violence against women or an average of 881 cases per day. Compared to the previous year, this figure increased by $9 \%$. While in the records of the Commission for the Protection of Indonesian Children, in the same year, there were 1,698 violent complaints against children, $53 \%$ of whom were cases of sexual violence. The remaining $40.7 \%$ are neglect, abuse, sexual exploitation, and other forms of violence (Wahyuningsih, 2015).

It may safely be concluded that violence against women and children are part of violence against humanity. In addition, the cause of violence is a crippled structure and structure, and the need to promote gender equality and justice for everyone. Thus, violence against people can be eliminated. Also, the controversy over settling cases of violence against women and children must be done by improving the biased 
and unequal legal substance, structure, and legal culture. It is urgent to state in this context that the need for assistance to women and children victims of violence, at least, should include four stages of awareness, healing, protection, and cooperation. Last but not least, the case of violence against women and children should be taken into a serious consideration in shaping and reconstructing Aceh after the tsunami and political conflict.

\section{CONCLUSION}

Hopefully, the development of Aceh after the Tsunami will not only be a model of any new development after a horrible disaster for the world but also give security and bring happiness to the Acehnese, especially the victims of Tsunami and Aceh conflict, who suffer so much from the disaster and the conflict. This sort of development may only be achieved if the gender equality, justice and the abolishment of misogynism, as well as no violence against women and children, are ensured. One of the important strategies to do so is by taking the so-called term "gender mainstreaming" into our serious consideration. Furthermore, a development is nothing, useless and unsuccessful, etc., if it ignores a collective, comprehensive and holistic participation of its whole people, including women. I am convinced that by applying a comprehensive, collective and holistic approach and participation -including women- towards Aceh development, the development of Aceh will have a better prospect for creating a better future for Aceh, Aamiin. 


\section{BIBLIOGRAPHIES}

Ahmed, Leila, Women and Gender in Islam, New York, 2000.

Ahmed, Durre S., Perspective on Islam: Cultural Complications, paper presented at Symposium on "Women and Religion, Debates on Searchheld on March 1996 at Chiang Mai, Thailand by Henrich Boll Foundation, 1997.

Ancel, Marc, Social Defence: a modern approach to criminal problem, Routledge \& Paul Kegan, London, 2012.

Arief, Barda Nawawi, Kebijakan Legislatif Dalam Penanggulangan Kejahatan Dengan Pidana Penjara, Ananta, Semarang, 1994

-----------, Bunga Rampai Kebijakan Hukum Pidana, Citra Aditya, Bandung, 1996

Badawi, J. , Gender Equity in Islam,. WAMY Studies on Islam. 1997.

BRR Aceh (Badan Rehabilitasi dan Rekonstruksi Aceh / Board for Rehabilitation and Reconstruction Aceh), quarterly report. 2005 - 2008.

Gosita, Arif, Masalah Korban Kejahatan, Akademika Presindd, Jakarta, 1983.

-, Perlindungan Anak , Akademika Presindo, Jakarta, 1983

Hakim, Murad Abdal, , Islam, Iriguaray, and the Retrieval of Gender, April 1999.

Muhsin; Amina Wadud, Quran and Woman, Kuala Lumpur 1992

Pecker, Herberth, The Limits of The Criminal Sanctions, Stanford, California, Stanford University Press, 1985

Smith; Margareth, Rabi a the Mystic and her Fellow-saints in Islam, Cambridge: Cambridge University Press, 1928.

Schulze, E. Kirsten E., The Free Aceh Movement (GAM): Anatomy of a Separatist Organization, (Washington: East-West Center, 2014);

Sukma, Rizal, Security Operations in Aceh: Goals, Consequences, and Lessons, (Washington: East-West Center, 2004).

Tappan, Paul, Juvenille Delinquency, Mc Graw Hill Book Company, Inc. , 1949

UNDP, Indonesia National Human Development Report 2004.

---------,Transition Recovery Unit, Bureau for Crisis Prevention and Recovery with UNDP Indonesia, Geneva, 17 April 2005.

United Nations, Human Rights A Compilatonof International Instruments (Volume I Second Part) Universal Instruments.

A Compilatonof International Instruments (Volume II Forts Part) Universal Instrrumens.

Wahyuningsih, Sri, a paper entitled, Tips to Toward a Harmonious and Prosperous Family, presented in a national seminar in the framework of the 42nd Brawijaya University Anniversary at Widyaloka Building on Saturday January 25th, 2015. 